Indo. J. Chem. Res., 2019, 7(1), 32-40

\title{
SENYAWA TRITERPENOID DARI EKSTRAK $N$-HEKSANA DAUN KELOR (Moringa oleifera Lamk.) DAN UJI AKTIVITAS ANTIBAKTERI TERHADAP Staphylococcus aureus Dan Escherichia coli
}

\section{Triterpenoid Compound From $n$-Hexane Extract of Kelor Leaves (Moringa oleifera Lamk.) And Antibacterial Activity Test Against Staphylococus aureus and Escherichia coli}

\author{
Yuszda Salimi $^{1}$, Nurhayati Bialangi ${ }^{1}$, Widysusanti Abdulkadir $^{2}$, Boima Situmeang ${ }^{3 *}$ \\ ${ }^{I}$ Department of Chemistry, Faculty of Mathematic and Natural Science, Gorontalo State University \\ ${ }^{2}$ Department of Pharmacy, Faculty of Sport and Natural Healty, Gorontalo State University \\ ${ }^{3}$ Department of Chemistry, Sekolah Tinggi Analis Kimia Cilegon, Banten \\ *Corresponding author, e-mail: boimatumeang@gmail.com
}

Received: Jan. 2019 Published: Jul. 2019

\begin{abstract}
Kelor plant (Moringa oleifera Lamk) is a natural nutrient source plant in the tropics. Moringa oleifera Lamk leaves are widely reported as natural antioxidants and anitbacterial. The purpose of this study was to isolate triterpenoid compound from n-hexane extract of kelor leaves. The sample extraction was performed by maceration method using methanol as a solvent. Fractionation used $n$-hexana and etil asetat as a solvent. The separation and purification of the compound was carried out by column chromatography method followed by stain pattern analysis with thin layer chromatography (TLC). Characterization and elucidation of pure compound structures using IR, ${ }^{1} \mathrm{H}-\mathrm{NMR},{ }^{12} \mathrm{C}-\mathrm{NMR}$, HSQC, HMBC, and ${ }^{1} \mathrm{H}-{ }^{1} \mathrm{H}$ COSY, and compared with various literatures. Based on the result of structural elucidation, the pure isolate obtained is a pentacyclic triterpenoid group compound with the molecular formula $\mathrm{C}_{30} \mathrm{H}_{50} \mathrm{O}$ and the name of 3-hydroxy, 20 (29) -en, lupenol. The triterpenoid compound of 3-hidroxy, 20 (29) -en, lupenol is the first isolated and reported from leaves of kelor plant.
\end{abstract}

Keywords: Kelor, triterpenoid, Esherichia coli, Staphylococcus aureus.

\section{PENDAHULUAN}

Indonesia memiliki sumber daya alam yang berlimpah dan mengandung jutaan senyawa kimia. Senyawa kimia berpotensi mengobati penyakit dan ada yang berpotensi sebagai racun. Tumbuhan dapat berpotensi sebagai pengobatan penyakit karena mengandung senyawa metabolit sekunder. Seiring dengan kemajuan ilmu pengetahuan dan teknologi dalam bidang kimia organik terbukti bahwa tumbuh-tumbuhan tertentu mengandung senyawa kimia yang penting bagi kesehatan manusia (Situmeang dkk, 2018).

Salah satu contoh tumbuhan yang biasanya digunakan sebagai pengobatan tradisional adalah tumbuhan kelor. Masyarakat Indonesia khususnya masyarakat pedesaan telah lama memanfaatkan kelor baik sebagai obat tradisional, sebagai sayuran, maupun makanan ternak. Keberadaan tumbuhan kelor sangat mudah didapatkan di seluruh wilayah Indonesia tidak terkecuali di daerah Gorontalo. Salah satu bagian tumbuhan kelor yang banyak dikonsumsi dan memiliki banyak manfaat adalah bagian daun (Madrona dkk., 2015; Isnan dan Nurhaedah, 2017).

Penelitian tentang daun kelor dilaporkan Chukwuebuka, (2015) menunjukkan bahwa hasil skrining fitokimia dari daun kelor mengandung senyawa metabolit sekunder di antaranya terpenoid, flavonoid, alkaloid, steroid, tanin, saponin, dan antrakuinon. Selain itu, Salimi dkk (2017), dari hasil penapisan fitokimia ekstrak metanol dan fraksi $n$-heksana daun kelor mengandung senyawa triterpenoid, flavonoid, dan steroid. Marcus dan Nwineewii, (2015) melaporkan hasil data Infra red (IR) menunjukkan ekstrak $n$-heksana mengandung terpenoid. Hasil penelitian tersebut membuktikan bahwa daun kelor mengandung 
senyawa metabolit sekunder dan salah satunya adalah senyawa triterpenoid.

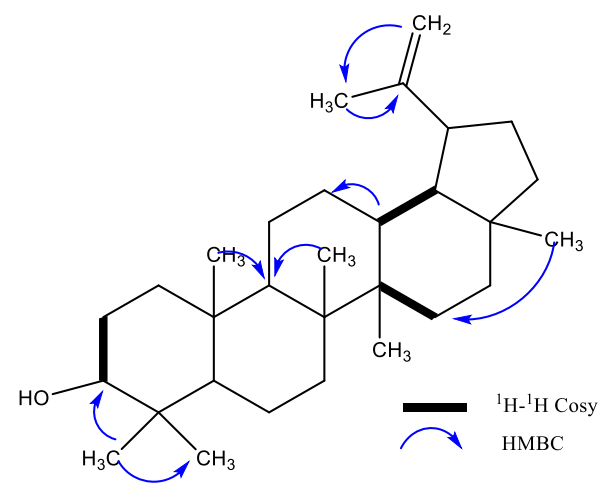

Gambar 1 Senyawa 3-hidroksi, 20 (29) -en, lupenol

Penelitian yang dilaporkan Napolean dkk, (2009) daun kelor berpotensi sebagai antimikroba, antikolesterol, antiinflamatori dari fraksi organik. Selain itu, Siddhuraju dan Becker, (2003) dari hasil uji aktivitas penangkapan radikal 1,1-difenil-2-pikrilhidrazil (DPPH) fraksi n-heksanadan fraksi etil asetat membuktikan bahwa aktivitas penangkapan radikal bebas cukup tinggi pada fraksi yang non polar (fraksi $n$-heksana). Sejalan dengan penelitian tersebut Agboke dan Attama (2016) melaporkan bahwa ekstrak n-heksana moringa oleifera dapat menghambat Staphylococcus Aureus. Berdasarkan hasil penelusuran pustaka, belum ada penelitian yang melaporkan kandungan senyawa kimia dari fraksi $n$-heksana daun kelor. Berdasarkan penelitian fraksi $n$-heksana daun kelor maka perlu dilakukan isolasi senyawa aktif antimikroba fraksi $n$-heksana dan uji aktivitas terhadap bakteri Staphilococus aureus dan Escherichia coli.

\section{METODOLOGI}

\section{Alat}

Peralatan yang digunakan dalam penelitian ini meliputi: maserator, evaporator, pipa kapiler untuk KLT, kolom kromatografi, kapas lidi, jangka sorong, autoclave dan laminar air flow. Pemantauan pemisahan dan pemurnian senyawa dilakukan dengan kromatografi lapis tipis (KLT) dengan lampu detektor UV $\lambda 254$ dan $365 \mathrm{~nm}$. Karakterisasi senyawa murni menggunakan alat spektrofotometer meliputi spektrometer infra merah (IR), ${ }^{1} \mathrm{H}-\mathrm{NMR},{ }^{13} \mathrm{C}-\mathrm{NMR},{ }^{1} \mathrm{H}-{ }^{1} \mathrm{H}$ COSY,
HSQC, dan HMBC di Laboratorium Kimia FMIPA Institut Teknologi Bandung.

\section{Bahan}

Sampel yang digunakan dalam penelitian ini adalah sampel daun tumbuhan kelor yang diambil dari Desa Barakati, kecamatan Batudaa, Gorontalo. Bahan kimia yang digunakan terdiri dari $n$-heksana (redes), etil asetat (redes), metanol (redes), metanol (p.a), etanol (p.a), silika gel G60 untuk kromatografi kolom dan silika gel $\mathrm{GF}_{254}$ untuk kromatografi lapis tipis, $\mathrm{H}_{2} \mathrm{SO}_{4} 10 \%$ (v/v) dalam etanol, TLC ODS RP-18, nutrient broth, bacto agar, amoxicillin 100 ppm, ciprofloxacin 100 ppm, dan akuades.

\section{Prosedur Kerja Persiapan Sampel dan Ekstraksi}

Sampel daun kelor segar sebanyak $4600 \mathrm{~g}$ diangin-anginkan dan diperoleh berat kering 1000 g. Daun kelor kering dirajang sampai menjadi serbuk kasar. Dari hasil perhitungan rendemen, diperoleh rendemen serbuk kasar daun kelor 21, 74\%. Sampel kemudian dimaserasi menggunakan metanol dengan volume $5 \mathrm{~L}$. Proses maserasi dilakukan selama $3 \times 24$ jam dan penyaringan dilakukan setiap $1 \times 24$ jam. Maserat total yang diperoleh di evaporasi menggunakan vacum rotary evaporator pada suhu $40^{\circ} \mathrm{C}$. Hasil evaporasi adalah ekstrak kental metanol sebanyak 167,69 g. Rendemen ekstrak kental metanol sebesar 16,77 \%.

Ekstrak kental metanol difraksinasi menggunakan metode partisi cair-cair. Ekstrak kental metanol sebanyak $100 \mathrm{~g}$ disuspensi dalam campuran air : metanol (2:1) dan dipartisi secara bertahap dengan $n$-heksana dan etil asetat. Dari tahap fraksinasi diperoleh fraksi $n$-heksana berwarna hijau kehitaman dan fraksi etil asetat berwarna coklat tua. Kedua fraksi tersebut dievaporasi pada suhu $40^{\circ} \mathrm{C}$ dan diperoleh ekstrak $n$-heksana dan ekstrak etil asetat. Ekstrak pekat etil asetat diperoleh sebanyak 10,87 $\mathrm{g}$ dan ekstrak n-heksana sebanyak 21,15 g.

\section{Isolasi Senyawa Triterpenoid}

Ekstrak pekat $n$-heksana sebanyak $21,15 \mathrm{~g}$ dipisahkan komponen senyawa kimia penyusunnya menggunakan metode kromatografi cair kolom terbuka dengan fasa diam silika gel G60 (70-230 mesh), dengan fase gerak menggunakan kombinasi pelarut $n$-heksana dan 
etil asetat, secara gradien, $10 \%$ dihasilkan 11 fraksi yaitu fraksi $1 \mathrm{~A}-1 \mathrm{~K}$.

Total volume pelarut per fraksi adalah 120 $\mathrm{mL}$ yang ditampung pada erlenmeyer $250 \mathrm{~mL}$. Setelah keseluruhan fraksi (1A-1K) diuapkan pelarutnya dengan rotary evaporator dilakukan analisis pemisahan pola nodanya dengan kromatografi lapis tipis (KLT) menggunakan kombinasi eluen $n$-heksana/etil asetat dengan perbandingan (7:3). Selanjutnya fraksi 1E dilakukan pemisahan lebih lanjut dengan kromatografi cair kolom terbuka menggunakan fasa diam silica gel, eluen $n$-heksana dan etil asetat bergradien $2 \%$.

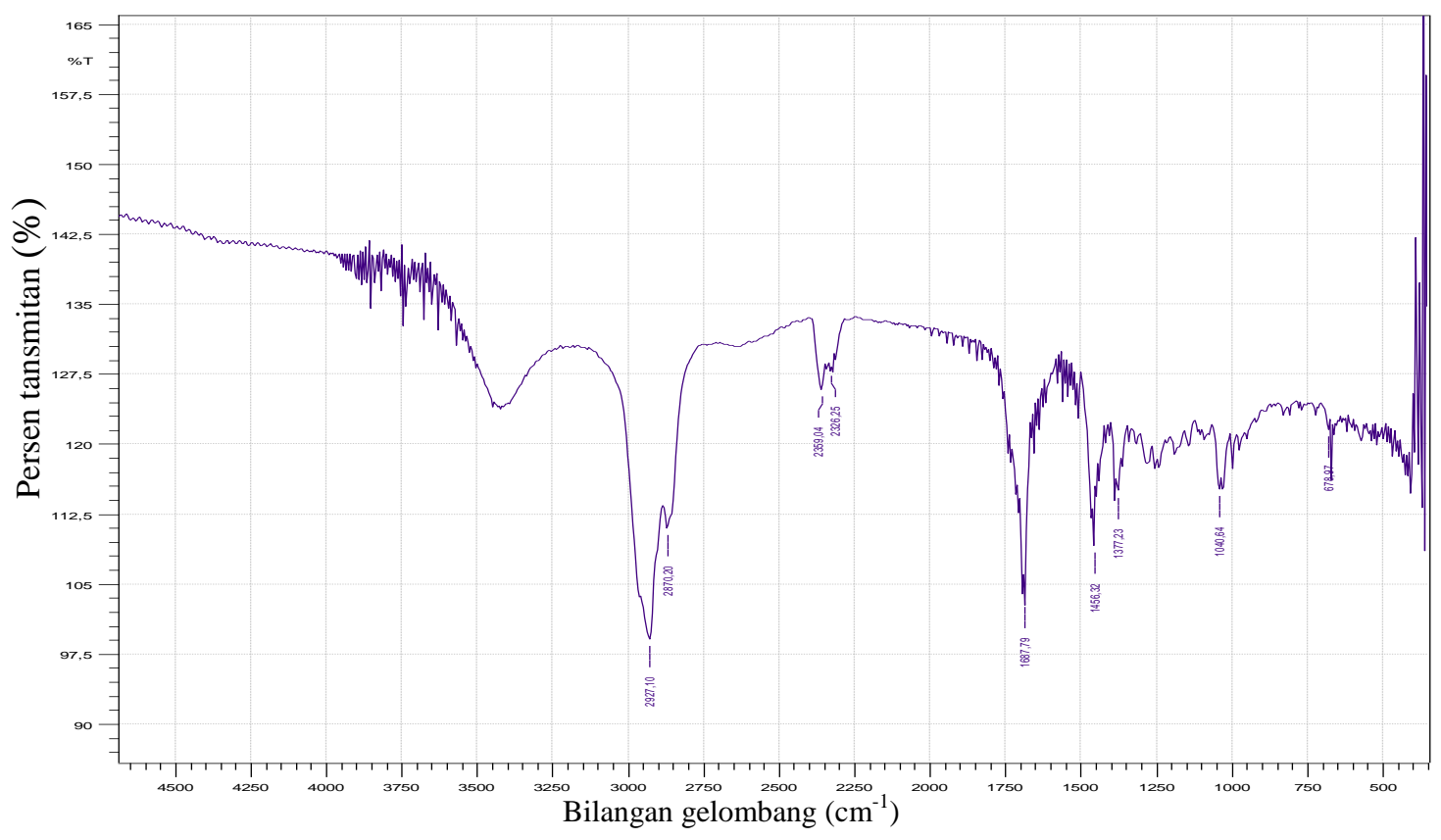

Gambar 2. Spekrum Inframerah (IR) Isolat dalam lempeng $\mathrm{KBr}$

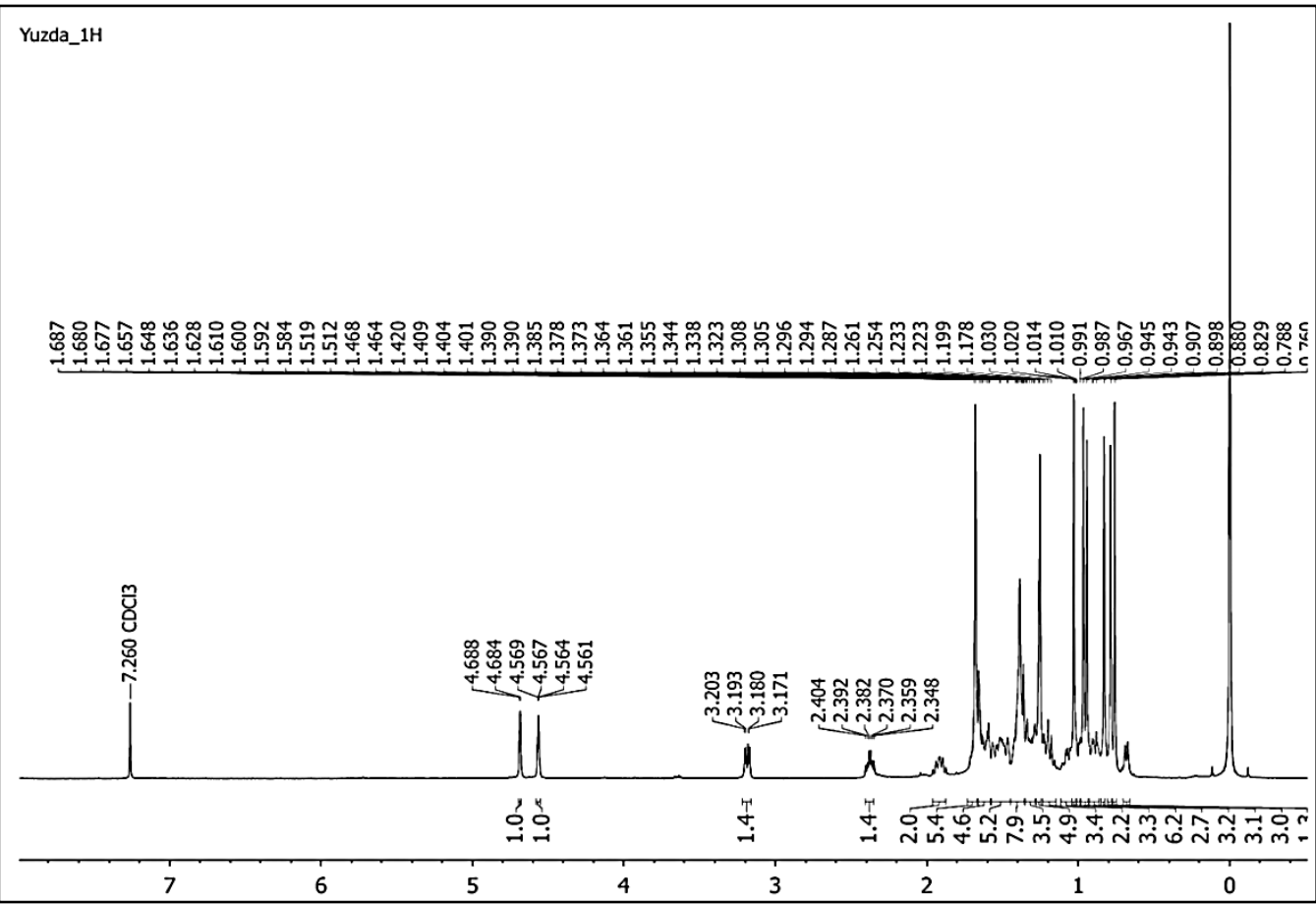

Gambar 3. Spektrum ${ }^{1} \mathrm{H}-\mathrm{NMR}$ Isolat $\left(500 \mathrm{MHz}, \mathrm{CDCl}_{3}\right.$ ) 
Yuszda Salimi dkk. / Indo. J. Chem. Res., 2019, 7(1), 32-40

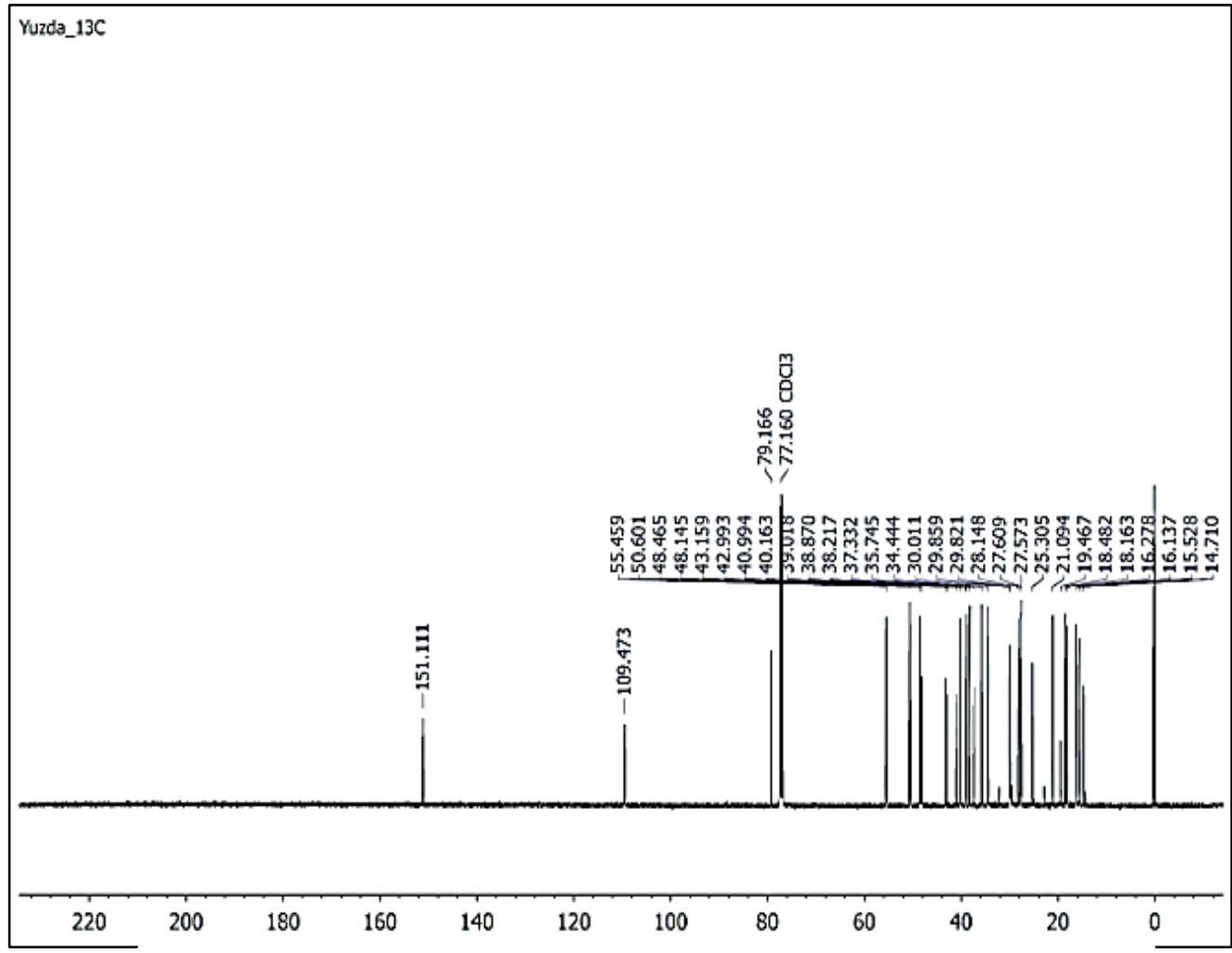

Gambar 4. Spektrum ${ }^{13} \mathrm{C}$-NMR Isolat (125 $\mathrm{MHz}, \mathrm{CDCl}_{3}$ )

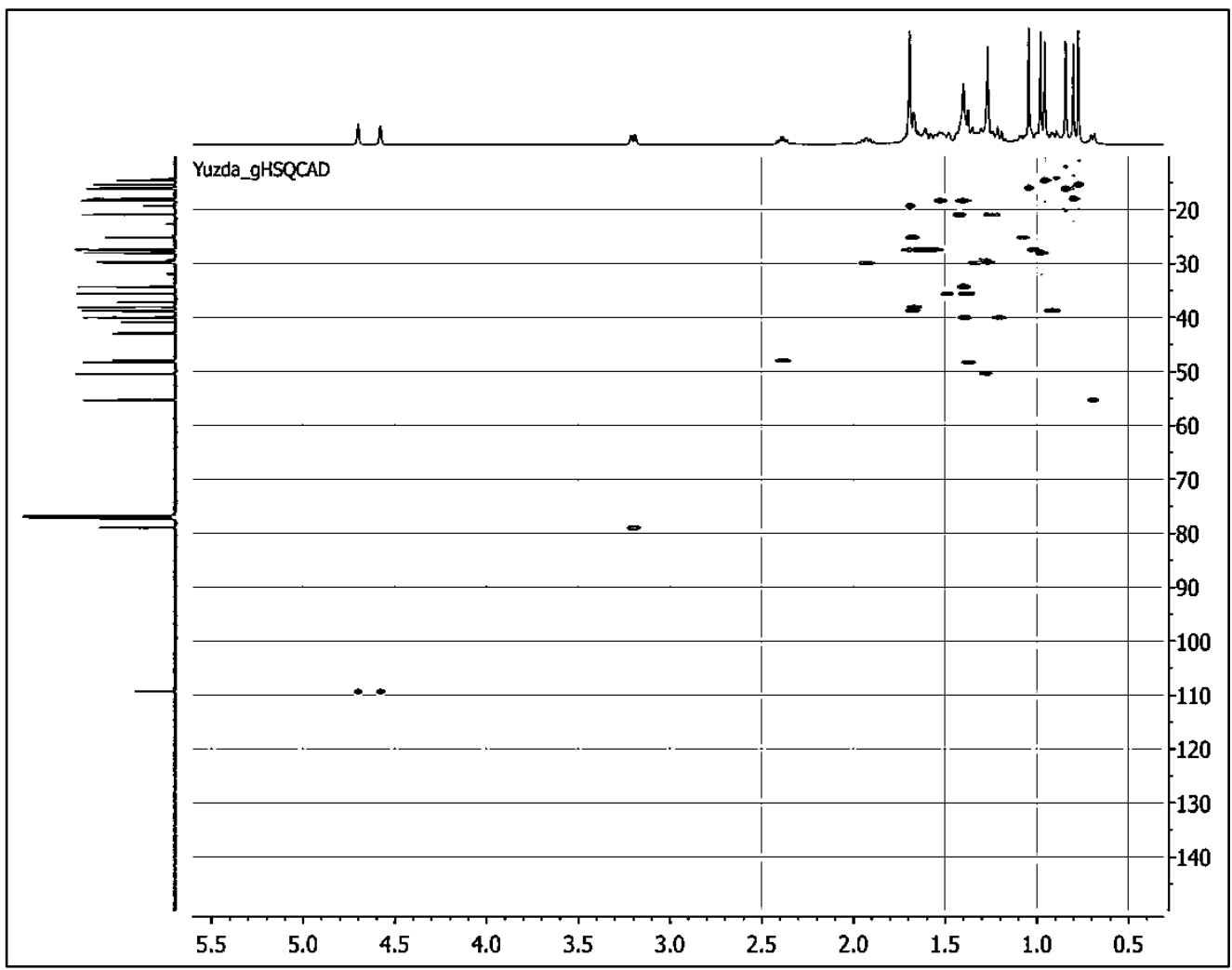

Gambar 5. Spektrum HSQC Isolat 
Dari hasil pemisahan diperoleh 30 fraksi yaitu fraksi 1E01-1E22. Terhadap keseluruhan fraksi dilakukan pemekatan dan dianalisis pemisahan pola nodanya dengan menggunakan kromatografi lapis tipis. Fraksi 1E11-14 memiliki pola noda dan nilai $\mathrm{Rf}$ yang sama sehingga dilakukan penggabungan untuk dimurnikan selanjutnya. Pemisahan selanjutnya dilakukan secara isokratik dengan pelarut $n$ heksana dan etil asetat perbandingan $(8,5: 1,5)$. Total volume yang ditampung sebanyak $10 \mathrm{~mL}$. Terhadap keseluruhan tampungan dilakukan analisis pola noda dengan KLT. Fraksi 1E11-10 sampai 1E11-21 menunjukkan dua pola noda, sehingga dilakukan pemurnian kembali menggunakan kromatografi kolom secara isokratik dengan pelarut $n$-heksana dan etil asetat perbandingan (9:1).

Total volume setiap tampungan adalah 5 $\mathrm{mL}$. Terhadap keseluruhan tampungan dilakukan analisis pola noda dengan KLT. Fraksi 1E11-1035 sampai 1E11-10-51 menunjukkan pola noda
NMR, ${ }^{13} \mathrm{C}-\mathrm{NMR},{ }^{1} \mathrm{H}-{ }^{1} \mathrm{H}$ COSY, HSQC, dan HMBC.

\section{Uji Aktivitas Antibakteri}

Senyawa murni hasil isolasi diuji aktivitas antibakteri terhadap bakteri patogen $S$. aureus dan E. coli dengan metode Kirby-Bauer. Kontrol positif antibiotik amoxicillin dengan konsentrasi $100 \mathrm{ppm}$ dan pelarut metanol sebagai kontrol negatif. Masing-masing sejumlah satu ose bakteri ( $S$. aureus dan E. coli) dari stok diinokulasi ke dalam erlenmeyer steril yang berisi media cair nutrient broth kemudian diinkubasi selama 18 jam pada temperatur $37^{\circ} \mathrm{C}$. Sebanyak $50 \mu \mathrm{L}$ suspensi bakteri yang telah diremajakan diolesikan ke atas permukaan cawan petri yang berisi media padat (NB + bacto agar) menggunakan kapas lidi. Sampel dengan variasi konsentrasi beserta kontrol positif dan kontrol negatif ditetesi pada paper disk sebanyak $15 \mu \mathrm{L}$.

Selanjutnya, paper disk diletakkan di atas media padat, diinkubasi pada suhu $37^{\circ} \mathrm{C}$ selama

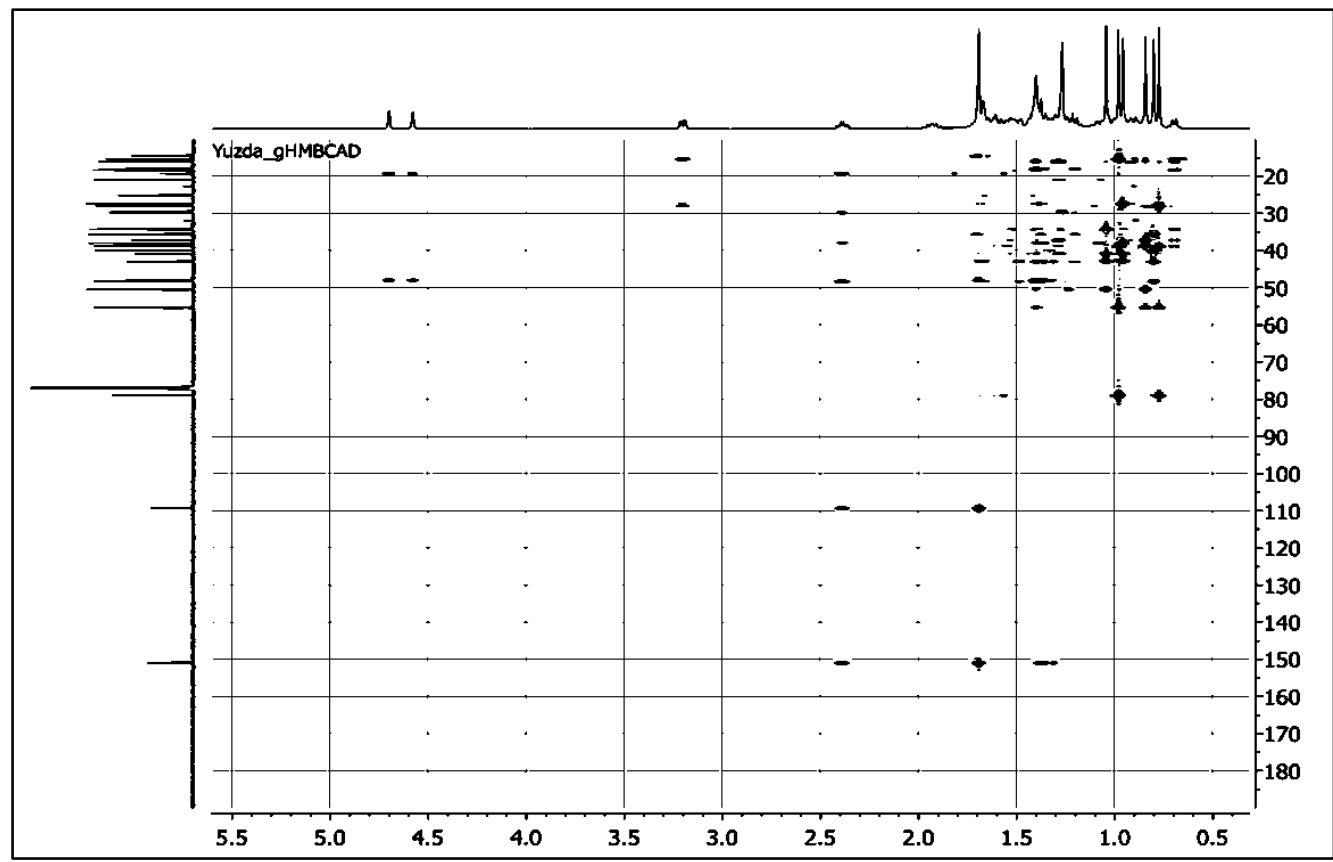

Gambar 6. Spektrum HMBC Isolat

tunggal berwarna pink. Selanjutnya dilakukan KLT dengan berbagai kombinasi pelarut (fasa normal dan fasa terbalik) untuk menguji kemurniannya. Total massa yang diperoleh sebanyak $6,01 \mathrm{mg}$. Selanjutnya terhadap isolat murni dilakukan karakterisasi dengan spektrofotometer UV, infra merah (IR), ${ }^{1} \mathrm{H}$ -
18 jam, dan diamati pertumbuhan bakteri. Zona inhibisi diukur menggunakan jangka sorong dengan skala millimeter (Singh dan Pandeya, 2011). 


\section{HASIL DAN PEMBAHASAN}

\section{Karakterisasi Senyawa}

Isolat murni yang diperoleh berupa kristal putih yang larut sempurna dalam etil asetat dan kloroform. Hasil pengukuran dengan spektroskopi UV isolat tidak berpendar pada UV $\lambda 254$ dan $365 \mathrm{~nm}$. Hal ini menunjukkan bahwa untuk mengetahui gugus fungsi yang terdapat dalam isolat. Spektrum IR isolat pada Gambar 2 (KBr) menunjukkan serapan gugus $\mathrm{O}-\mathrm{H}(3431,0$ $\mathrm{cm}^{-1}$ ) diikuti dengan serapan pada bilangan gelombang $1061,2 \mathrm{~cm}^{-1}$ yang merupakan regangan ulur dari gugus $\mathrm{C}-\mathrm{OH}$. Pada bilangan gelombang $2977,17 \mathrm{~cm}^{-1}$ terdapat regangan ulur

Tabel 1. Data NMR (500 MHz untuk ${ }^{1} \mathrm{H}-\mathrm{NMR}$ dan $125 \mathrm{MHz}$ untuk $\left.{ }^{13} \mathrm{C}-\mathrm{NMR}\right)$.

\begin{tabular}{|c|c|c|c|c|}
\hline $\begin{array}{l}\text { Posisi } \\
\text { C }\end{array}$ & $\begin{array}{l}{ }^{13} \mathrm{C}-\mathrm{NMR} \\
\delta_{\mathrm{C}}(\mathrm{ppm})\end{array}$ & HSQC & $\begin{array}{c}{ }^{1} \text { H-NMR } \\
\delta_{H}(\text { Int., mult., J=Hz) }\end{array}$ & $\begin{array}{l}\text { HMBC } \\
{ }^{1}{ }_{\mathrm{H} \rightarrow{ }^{13}} \mathrm{C}\end{array}$ \\
\hline 1 & 40,1 & $\mathrm{CH}_{2}$ & $1,19(1 \mathrm{H} ; \mathrm{s}) \& 1,43(1 \mathrm{H} ; \mathrm{m})$ & C-5 \\
\hline 2 & 28,2 & $\mathrm{CH}_{2}$ & $1,65(2 \mathrm{H} ; \mathrm{m})$ & - \\
\hline 3 & 79,1 & $\mathrm{CH}$ & $3,19(1 \mathrm{H} ; \mathrm{dd})$ & $\mathrm{C}-23$, \\
\hline 4 & 40,9 & $\mathrm{Cq}$ & - & - \\
\hline 5 & 55,5 & $\mathrm{CH}$ & $0,83(1 \mathrm{H} ; \mathrm{s})$ & - \\
\hline 6 & 19,5 & $\mathrm{CH}_{2}$ & $1,42(1 \mathrm{H} ; \mathrm{m}) \& 1,57(1 \mathrm{H} ; \mathrm{m})$ & C-8, 10 \\
\hline 7 & 35,7 & $\mathrm{CH}_{2}$ & $1,55(2 \mathrm{H} ; \mathrm{m})$ & C-5 \\
\hline 8 & 43,1 & $\mathrm{Cq}$ & - & - \\
\hline 9 & 50,4 & $\mathrm{CH}$ & $1,38(1 \mathrm{H} ; \mathrm{m})$ & $\mathrm{C}-11$ \\
\hline 10 & 38,2 & $\mathrm{Cq}$ & - & - \\
\hline 11 & 26,9 & $\mathrm{CH}_{2}$ & $1,62(2 \mathrm{H} ; \mathrm{m})$ & - \\
\hline 12 & 28,8 & $\mathrm{CH}_{2}$ & $1,65(2 \mathrm{H} ; \mathrm{m})$ & - \\
\hline 13 & 41,0 & $\mathrm{CH}$ & $0,75(1 \mathrm{H} ; \mathrm{m})$ & $\mathrm{C}-18,19,27$ \\
\hline 14 & 39,0 & $\mathrm{Cq}$ & - & - \\
\hline 15 & 30,0 & $\mathrm{CH}_{2}$ & $1,22(2 \mathrm{H} ; \mathrm{m})$ & - \\
\hline 16 & 38,9 & $\mathrm{CH}_{2}$ & $1,3(1 \mathrm{H} ; \mathrm{m}) \& 1,9(1 \mathrm{H} ; \mathrm{m})$ & - \\
\hline 17 & 48,4 & $\mathrm{Cq}$ & - & - \\
\hline 18 & 48,7 & $\mathrm{CH}$ & $0,96(1 \mathrm{H} ; \mathrm{m})$ & $\mathrm{C}-19,20$ \\
\hline 19 & 48,1 & $\mathrm{CH}$ & $2,41(1 \mathrm{H} ; \mathrm{m})$ & $\mathrm{C}-18,20,29,30$ \\
\hline 20 & 151,1 & $\mathrm{Cq}$ & - & - \\
\hline 21 & 34,8 & $\mathrm{CH}_{2}$ & $0,79(1 \mathrm{H} ; \mathrm{s}) \& 2,3(1 \mathrm{H} ; \mathrm{dt})$ & - \\
\hline 22 & 35,9 & $\mathrm{CH}_{2}$ & $1,48(2 \mathrm{H} ; \mathrm{m})$ & C-17, 22 \\
\hline 23 & 14,5 & $\mathrm{CH}_{3}$ & $0,95(3 \mathrm{H} ; \mathrm{s})$ & $\mathrm{C}-3,4$ \\
\hline 24 & 15,5 & $\mathrm{CH}_{3}$ & $0,98(3 \mathrm{H} ; \mathrm{s})$ & $\mathrm{C}-3,5$ \\
\hline 25 & 18,5 & $\mathrm{CH}_{3}$ & $0,83(3 \mathrm{H} ; \mathrm{s})$ & $\mathrm{C}-1$ \\
\hline 26 & 16,2 & $\mathrm{CH}_{3}$ & $0,75(3 \mathrm{H} ; \mathrm{s})$ & C-8 \\
\hline 27 & 18,2 & $\mathrm{CH}_{3}$ & $1,00(3 \mathrm{H} ; \mathrm{s})$ & $\mathrm{C}-13,15$ \\
\hline 28 & 29,8 & $\mathrm{CH}_{3}$ & $1,00(2 \mathrm{H} ; \mathrm{s})$ & - \\
\hline 29 & 109,5 & $\mathrm{CH}_{2}$ & $4,6(1 \mathrm{H} ; \mathrm{J}=2.55 ; \mathrm{d}) ; 4,5(1 \mathrm{H} ; \mathrm{q})$ & $\mathrm{C}-19,20,30$ \\
\hline 30 & 21,1 & $\mathrm{CH}_{3}$ & $1,02(3 \mathrm{H} ; \mathrm{s})$ & $\mathrm{C}-20$ \\
\hline
\end{tabular}

isolat tidak memiliki karbon terkonjugasi yang merupakan salah satu ciri khas senyawa triterpenoid (Abdullah dkk., 2013). Selanjutnya dilakukan pengukuran spektrum inframerah gugus $\mathrm{C}-\mathrm{H}$ alifatik diikuti dengan serapan pada $1458,70 \mathrm{~cm}^{-1}$ yang merupakan tekukan $\mathrm{C}-\mathrm{H}$ pada $1370,33 \mathrm{~cm}^{-1}$ yang merupakan regang geminal dimetil (Martins dkk., 2013; Situmeang 
dkk, 2018). Spekrum ${ }^{1}$ H-NMR (Gambar 3) menunjukkan resonansi untuk proton olefinik pada pergeseran $\delta 4,68$ dan 4,56 ppm $(2 \mathrm{H})$. Proton hidroksil pada $\delta 3,19 \mathrm{ppm}(1 \mathrm{H}$; dd, $\mathrm{J}=$ $11,0 ; 3,9 \mathrm{~Hz})$ menunjukkan posisi aksial dan orientasi $\alpha$. Terdapat tujuh metil singlet pada $\delta$ 0,$75 ; 0,83 ; 0,95 ; 0,98 ; 1,00 ; 1,00$ dan $1,02(3 \mathrm{H})$ ppm menunjukkan bahwa isolat merupakan golongan senyawa triterpenoid pentasiklik (Prakash dan Prakash, 2012; Situmeang dkk, 2018). Tumpukan sinyal pada rentang $\delta: 0,96-$ 2,40 ppm diduga merupakan pergeseran kimia untuk proton yang terikat pada rantai karbon triterpenoid (Prakash dan Prakash, 2012).

Spektrum ${ }^{13} \mathrm{C}-\mathrm{NMR}$ isolate pada Gambar 4 memperlihatkan adanya tiga puluh sinyal karbon yang terdiri dari 28 atom karbon sp3, dua atom karbon olifenik $\mathrm{C}=\mathrm{C}$ sp2 . Pada pergeseran 79,1 ppm merupakan pergeseran yang khas terhadap karbon yang teroksigenasi pada senyawa triterpenoid. Pergeseran kimia di bawah $\delta 79,1$ ppm menunjukkan atom karbon sp3 alifatik yang dapat berupa rantai lurus ataupun siklik yang diduga berasal dari rantai alifatik golongan triterpenoid pentasiklik (Prakash dan Prakash, 2012). ikatan rangkap yang terdapat pada senyawa triterpenoid lupenol pada nomor 20 dan 29.

Adanya sinyal metilen sp2 pada pergesaran $\delta$ 109,5 ppm menunjukkan bahwa ikatan rangkap merupakan terminal double bond bukan internal double bond. Ikatan rangkap ini memberikan sumbangan satu derajat ketidakjenuhan. Hasil pengukuran HSQC (Gambar 5) menunjukkan dugaan rumus molekul isolat adalah $\mathrm{C} 30 \mathrm{H} 50 \mathrm{O}$. Dari dugaan rumus molekul tersebut, diperoleh nilai double bond equivalen (DBE) sebesar 6 . Dugaan isolat merupakan triterpenoid pentasiklik memberikan sumbangan derajat ketidakjenuhan sebesar lima. Sumbangan dari terminal double bond sebesar satu.

Hasil pengukuran spektrum HMBC pada Gambar 6 menunjukkan bahwa proton $\mathrm{H}-13(\delta \mathrm{H}$ $0,75 \mathrm{ppm})$ berkorelasi dengan $\mathrm{C}-12(\delta \mathrm{C} 28,1$ ppm), H-26 ( $\delta \mathrm{H} 0,75 \mathrm{ppm})$ memiliki korelasi dengan $\mathrm{C}-10(\delta \mathrm{C} 38,9 \mathrm{ppm}), \mathrm{H}-23(\delta \mathrm{H} \quad 0,95$ ppm) memiliki korelasi dengan $\mathrm{C}-24(\delta \mathrm{C} 16,2$ ppm), dan $\mathrm{H}-28$ ( $\delta \mathrm{H} 1,0 \mathrm{ppm})$ memiliki korelasi dengan $\mathrm{C}-15$ ( $\delta \mathrm{C} 30,9 \mathrm{ppm})$. Posisi gugus fungsi alkohol dapat ditentukan melalui korelasi HMBC antara karbon dan proton yaitu $\mathrm{H}-23(\delta \mathrm{H} 0,95$ ppm) dengan C-3 ( $\delta \mathrm{C} 79,1 \mathrm{ppm})$. Selanjutnya

Tabel 2. Hasil uji aktivitas antibakteri senyawa lupenol

\begin{tabular}{cccc}
\hline \multirow{2}{*}{ sampel } & \multirow{2}{*}{ Konsentrasi } & \multicolumn{2}{c}{ Zona hambat $(\mathbf{m m})$} \\
\cline { 3 - 4 } & $100 \mu \mathrm{g} / \mathrm{mL}$ & E. coli & S. aureus \\
\hline Lupenol & $100 \mu \mathrm{g} / \mathrm{mL}$ & 12.9 & 8 \\
amoxicillin & $100 \mu \mathrm{g} / \mathrm{mL}$ & $\mathrm{td}$ & $\mathrm{td}$ \\
ciprofloxacin & $96 \%$ & 0 & 13 \\
metanol & & & 0 \\
\hline
\end{tabular}

Hasil pengukuran spektrum HSQC menunjukkan bahwa isolat memiliki tiga puluh sinyal karbon yang terdiri dari tujuh atom karbon metil pada $\delta 14,7 ; 15,5 ; 16,2 ; 18,2 ; 18,5 ; 21,1$ dan $29,8 \mathrm{ppm}$. Enam sinyal metin yang terdiri dari metin $s p^{3}$ pada $\delta 41,0 ; 48,7 ; 48,1 ; 50,4 ; 55,5$ dan 79,2 ppm. Sebelas atom karbon metilen pada $\delta 19,5 ; 26,9 ; 28,2 ; 28,8 ; 30,0 ; 34,8 ; 35,7 ; 35,9$; 38,9; 40,1 dan 109,5 ppm. Jumlah atom karbon kuartener sebanyak enam, lima diantaranya merupakan karbon kuartener $s p^{3}$ pada pergeseran $\delta 40,9 ; 43,1 ; 38,2 ; 39,0$; dan 48,4 ppm dan satu diantaranya karbon kuartener $s p^{2}$ pada $\delta 151,1$ ppm. Adanya sinyal karbon metilen dan karbon kuartener $s p^{2}$ pada pergesaran $\delta 109,5$ dan 151,1 ppm menunjukkan bahwa isolat memiliki satu ikatan rangkap dan juga merupakan ciri khas posisi gugus fungsi $\mathrm{C}=\mathrm{C} s p 2$ dapat ditentukan melalui korelasi yaitu $\mathrm{H}-30$ ( $\delta \mathrm{H} \quad 1,02 \mathrm{ppm})$ berkorelasi dengan C-20 ( $\delta \mathrm{C} \quad 151,1 \quad \mathrm{ppm})$. Adanya korelasi $\left({ }^{3} J\right)$ dari proton milik karbon C23 ( $\delta$ 15,5 ppm) dengan karbon C-24 ( $\delta$ 16,2 ppm) dan sebaliknya menyarankan posisi geminal dimetil (Silva dkk., 2012; Babalola dan Shode, 2013; Chudzik dkk., 2015).

Spektrum H-H COSY digunakan untuk mengetahui proton-proton yang berkorelasi dengan jarak tiga ikatan. Pada spektrum ${ }^{1} \mathrm{H}-{ }^{1} \mathrm{H}$ COSY dapat diamati bahwa $\mathrm{H}-13(\delta \mathrm{H} 0,75 \mathrm{ppm})$ berkorelasi dengan $\mathrm{H}-18$ ( $\delta \mathrm{H} 0,96 \mathrm{ppm}), \mathrm{H}-15$ $(\delta \mathrm{H} 1,2 \mathrm{ppm})$ berkorelasi dengan $\mathrm{H}-27(\delta \mathrm{H} 1,0$ ppm), dan $\mathrm{H}-2$ ( $\delta \mathrm{H} 1,65 \mathrm{ppm})$ berkorelasi dengan H-3 (3,19 ppm). Data hasil pengukuran spectrum NMR isolate ditunjukkan pada Tabel 1. Setelah dilakukan analisis terhadap spektrum ${ }^{1} \mathrm{H}$ 
NMR, karbon ${ }^{13} \mathrm{C}$ NMR, HSQC, ${ }^{1} \mathrm{H}-{ }^{1} \mathrm{H}$ COSY, dan $\mathrm{HMBC}$ serta perbandingan dengan berbagai senyawa referensi, maka isolate diduga merupakan senyawa triterpenoid pentasiklik yaitu 3-hydroxy, 20 (29) -en, lupenol (Gambar 1).

Karakteristik yang khas dari senyawa ini yaitu adanya gem dimetil dan satu ikatan rangkap pada karbon nomor 20 (29). Gugus gem dimetil tersebut terletak pada karbon nomor 23 dan 24 dan adanya terminal double bound pada karbon nomor 20 dan metilen $\mathrm{sp}^{2}$ pada karbon nomor 29. Senyawa ini mempunyai rumus molekul $\mathrm{C}_{30} \mathrm{H}_{50} \mathrm{O}$ dengan jumlah derajat ketidakjenuhan sebanyak enam. Nama IUPAC dari senyawa ini adalah 3-hidroksi, 20(29)-en lupenol (Ayotollahi et al., 2011; Babalola \& Shode, 2013; Chudzik et al., 2015).

Berdasarkan penelusuran pustaka, senyawa 3-hidroksi, 20(29)-en lupenol sudah banyak diisolasi dari tumbuhan dan berasal dari jalur biosintesis asam mevalonat. Senyawa lupenol terbukti sebagai antiurolitiatik sebagaimana yang telah dilaporkan Abdullah et al., (2013). Penelitian Li et al, (2018) melaporkan senyawa lupenol sebagai agen kemopreventif, memiliki aktivitas antibakteri dan antiinflamasi. Senyawa triterpenoid 3-hidroksi, 20(29)-en lupenol merupakan pertama kali diisolasi dari ekstrak $n$ heksana daun kelor.

\section{Aktivitas Antibakteri Senyawa Lupenol}

Hasil uji antibakteri terhadap bakteri E. coli dan $S$. aureus senyawa lupenol ditunjukkan pada Tabel 2. Senyawa lupenol memiliki aktivitas antibakteri yang kuat terhadap bakteri $S$. aureus dan E. coli walaupun tidak melampui zona hambat senyawa standar amoxicillin dan ciprofloxacin. Senyawa lupenol memiliki nilai zona hambat yang lebih tinggi terhadap bakteri $S$. aureus dibandingkan dengan $E$. coli.

\section{KESIMPULAN}

Dari sampel daun kelor sebanyak $1 \mathrm{~kg}$ telah diisolasi senyawa lupenol dari ekstrak $n$-heksana sebanyak 6,01 mg. Berdasarkan hasil elusidasi struktur, isolat murni yang diperoleh merupakan senyawa golongan triterpenoid pentasiklik dengan rumus molekul $\mathrm{C}_{30} \mathrm{H}_{50} \mathrm{O}$ dan nama 3hidroksi, 20(29)-en, lupenol. Senyawa lupenol memiliki aktivitas antibakteri terhadap E. coli dan $S$. aureus yang tergolong sedang. Senyawa triterpenoid pentasiklik lupenol merupakan yang pertama kali diisolasi dari daun kelor.

\section{UCAPAN TERIMA KASIH}

Penulis mengucapkan terimakasih kepada DRPM Kementerian Riset Teknologi dan Pendidikan Tinggi atas hibah Penelitian Terapan Unggulan Perguruan Tinggi tahun 2018 dan Dr. Elvira atas pengukuran spektrum NMR di Laboratorium NMR Institut Teknologi Bandung (ITB).

\section{DAFTAR PUSTAKA}

Abdullah, S.M., Musa, A.M., Abdullah, M.I, Sule, M., Sany, Y.M., 2013, Isolation of lupenol from the Steam Bark of Lonchocarpus sericeus, Sch. Acad, J. Brosci., 1(1), 18-21.

Agboke, A.A., and Attama, A.A., 2016, Bioactive Components and Antibacterial Activities of $n$-Hexane Extract of Moringa Oleifera Root Bark on Clinical Isolates of Methicilin Resistant Staphylococcus Aureus, Int. J. Curr. Res. Chem. Pharm. Sci., 3(3), 1-9.

Ayotollahi, A.M., Ghanadian, M., Afsaridove, S., Abdella, O.M., Murzai, M., Aiskan, G., 2011, Pentacyclic Triterpenes in Euphorbia Microsciadia with their T-Cell Profiration Activity, Irian J.Pharmac, 10, 287-294.

Babalola, I., and Shode, F., 2013, A Potential Pentacyclic Triterpens Natural Product, J. of Pharmacognosy and phytochemistry., 2(2), 214-222.

Chukweubuka, E., 2015, Moringa oleifera "The Mother's Best Friend", Int. J. of Nutrition and Food Sciences., 4(6), 624-630.

Chudzik, M., Korzonek, I.S, Kroe, W., 2015, Triterpenes as Potentially Cytotoxic Compounds, Molecules, 20, 1610-1625.

Fitriana, W.D., Fatmawati, S., Ersam T., 2015, Uji aktivitas antioksidan terhadap DDPH dan ABTS dari fraksi-fraksi daun kelor (Moringa oleifera), Jurnal Prosiding Simposium Nasional Inovasi dan Pembelajaran Sains 2015 (SNIPS 2015) 8 dan 9 Juni 2015, Bandung.

Isnan, W., dan Nurhaedah M., 2017, Ragam manfaat Tanaman Kelor (Moringa olivera lamk), Info Teknis EBONI, 14 (1): 62-75. 
Li, X.J., Zou, Q.P., Wang, X., Kim, K.W., Lu, M.F., Ko, S.K., Yook, C.S., Kim, .YC., Liu, X.Q., 2018, Lupane Triterpenes from the Leaves of Acanthopanax gracilistylus, Molecules, 23, 87-93.

Marcus, A.C., and Nwineewii, J.D., 2015, Studies on the Crude Extract of Moringa oleifera Leaves for Preliminary Identification of some Phytochemicals and Organic Functions, J. of Applied Chem., 8 (2), $1-5$

Martins, D., Carrion, L.L., Ramos, D.F., Salome, K.S., Silva, P.A., 2013, Triterpenes and Antimicrobial of Durorra macopyhlla Huber (Rubiaceae), J. Biomed., 7, 10155/605831.

Napolean, p., Anitha, J., Renitta, E., 2009, Isolation, Analysis and Identification of Phytochemicals of Antimicrobial Activity of Moringa oleifera Lam, J. Current. biotika, 3(1), 33-39.

Prakash, C.V., and Prakash, I., 2012, Isolation and Structural Characterization of Lupane Triterpenes from Polypodium vulgare, Res. J. Pharm., 1(1), 23-27.
Salimi, Y.K., Bialangi, N., Saiman., 2017, Isolasi dan Identifikasi Senyawa Metabolit Sekunder Ekstrak Metanol Daun Kelor (Moringa Oleifera Lamk), J. Akademika, 6(2), 5-11.

Siddhuraju, P., and Becker, K., 2003, Antioxidant Properties of Various Solvent Extracts of Total Phenolic Constituents from three Different Agro-Climatic Origins of Drumstick Tree (Moringa oleifera Lam.), J. Agric. Food Chem., 15, 2144-2155.

Silva, D.L., David, J., Silva, L., Santos, R., David, J., Lima, L., Reis, P., Fontane, R., 2012, Bioactive Oleanoat, Lupinee and Ursane Triterpenoid Acid Derivates, Molecules, 17, 12197-12205.

Singh, G. S. and Pandeya, S. N. 2011. Natural Product in Discovery of Potential and Safer Antibacterial Agent, Natural Product in Medicinal Chemistry. 63-101: 978-81-3080448-4.

Situmeang, B., Suparman, A.R., Kadarusman, M., Herlina, T., 2018, Isolasi senyawa Triterpen dari Ekstrak Etil Asetat Tumbuhan Pirdot (Sauauria vulkani Kurth.), J. Kimia Valensi, 4 (2), 92-97. 